\title{
Discussion on How Extension Strategies Works to Prevent Product Sales from Declining
}

\author{
Jiajie Jin \\ Durham University, UK \\ Email: joey_king1016@qq.com
}

\begin{abstract}
This study aims to investigate effective extension strategies on products during different stages of product life cycle. By evaluating and categorize several existing realistic cases, the study finds that product promotion and product adjustment have been widely used to extend product life cycle. Under these two categories, holding marketing campaigns, targeting new markets, finding new unique selling points, finding new uses, extending product range and providing a new appearance are the main extension and effective strategies that companies widely use.

Keywords: extension strategies, product life cycle, product promotion, product adjustment
\end{abstract}

\section{Introduction}

According to Chris Fill (2002), the Product Life Cycle is an explanation and prediction of a product's position. In general terms, it can be separated into several stages which are quite similar to a human's life course. After a product has been developed and put into the market, it comes through the introduction stage to growth followed by maturity and then ends with decline. By following these steps, companies can work out a plan for their marketing activities (Marcouse, Watson and Hammond, 2015). Once the market is saturated with the product, sales decline is inevitable. In order to gain more profits, companies need to look for some extension strategies to prolong the product's life. Product promotion and product adjustment are two types of strategies that companies mainly use. On one hand, product promotion is a powerful method for firms to obtain more profits on their existing products. Usually, companies promote their newly launched products in order to attract customers' attention. However, some companies also use this strategy as a way to hold on to consumers as well as to attract them. In this situation, the staff of the company work out plans to focus more on how to remind their customers about the existing products their company has. On the other hand, adjusting the product is another main strategy. This method works well especially when the existing product no longer meets the public's needs and demands (van Daalen, 2012). This essay will mainly focus on six points that are aspects of the two main extension strategies and how they work to prevent product sales from declining.

\section{Six main extension and effective strategies that companies widely use}

\subsection{Holding marketing campaigns}

First of all, since holding events is the fastest way to attract the attention of the public, holding big advertising campaigns is always regarded as a first choice to promote existing products by some companies. For example, Heineken once held a campaign called "Open Your World" in 2017, including the Publicis film "Worlds Apart", an advertisement for it. Strangers who have contrary beliefs are put together in pairs and given a cooperative mission to fulfil before knowing each other's beliefs. Finally, they are allowed to have a choice of whether to leave or stay, and they discuss this together over a beer. This video mainly aims to show that people who own different opinions can still find popular similarities by getting together over a Heineken beer. Heineken benefited a lot by gaining free promotion due to the resulting heated discussion among the public and sales of the beer increased around 4 percent in the first two quarters of 2017 (Marketing Week Reporters, 2017). However, although holding such a heated campaign worked out for Heineken, when it came to Pepsi, it turned out to be a failure. Pepsi updated a new advertisement talking about peace for its campaign "Live for Now" in 2017. It talked about a demonstration opposing police violence against black people. As a matter of fact, the video ended with an actress handing a can of Pepsi to a police office and the crowd smiling, drinking bottles of Pepsi and shouting for peace in a demonstration for peace (Hobbs, 2017). It made it appear that a political problem could be solved with entertainment and a bottle of fizzy drink. Because of this the advertisement, Pepsi was criticized by the audience intensely and this led to a drop in its product's sales. Comparison with Heineken suggests their beer naturally and appropriately featured in the advertisement, while few associations could be seen between Pepsi and the peace protest. Rather than shouting out the slogan and focusing 
on entertainment, companies should think twice when using political topics to promote their products. So, it clearly shows that a good campaign can make a positive impression on customers and get unexpected promotion for the product if it works.

\subsection{Targeting new markets}

Targeting new markets is another way included in product promotion to prolong the existing products' life cycle. Through this approach a company can either develop in related areas or globalize. Companies which expect to add value to their mature products will especially focus on those areas related to the existing product. For instance, Vanke developed byproducts to optimize their original housing products. As a leading real estate corporation, Vanke has gone into many areas such as education, elderly care services and property services in the past three decades. Based on their solid foundation in residential areas, they want to provide buyers with well-equipped housing and real estate services (China Vanke Co.,Ltd, n.d.). These by-products no doubt proved helpful in increasing their housing trading volume, because residents felt satisfied with the thoughtful services the company provided. Other than extending companies' business domains, spreading overseas is another choice. When companies start projects or have branches in foreign countries, it brings them more potential buyers. Returning to Vanke, this company has turned to investing in residential projects overseas in recent years. Up to the year 2017 Vanke has already entered 7 foreign cities (China Vanke Co.,Ltd, n.d.). Since Vanke is on its way to globalizing, more and more profits in overseas' markets can be seen in its annual report for 2016 which Vanke put on its website (Vanke Real Estate (Hong Kong) Company Limited, 2017). As companies bring their products to the world, their products gain more extension opportunities. It is worth mentioning that it can be seen clearly from Forbes world leading brands that those which hold a place at the top of the list are mostly owned by international corporations (Forbes Media LLC., 2018). It seems that global companies are more capable of maintaining their product because they are dealing with a larger scale of customers. To sum up, both develop by-products and being international are aimed at promoting main product to more customers and it can lead to sales increases because more people get interested in these products.

\subsection{Finding new unique selling points}

A unique selling point is the symbol to distinguish a product from its similar competitors. As an increasing number of rival commodities spring up in the industry, there is more risk of a product being substituted by other products. In that case it is necessary for companies to find new selling points especially when the products are becoming unappealing to their consumers. The Kishigawa Line, a rail line in Japan is a good example. This rail line was once nearly bankrupt because of financial difficulties and a decline in passengers every year. However, a significant increase in its finances can be seen after the operations company decided to appoint a cat named "Tama" as their new stationmaster (McCurry, 2015). Tama's swearing-in ceremony was filmed and uploaded to the internet and news reports about this event continuously emerged at that time. Since then stories about Tama have spread by word of mouth. People showed a great positive response to the new stationmaster and travellers who were interested in the rail cat came all the way from other cities and even other countries to visit Tama. According to a report in The Guardian (McCurry, 2015) during the period when Tama was in her position, The Kishigawa Line earned more than one hundred million yen. The large number of tourists brought in by the cat stationmaster always visited at the station's cat theme café and bought souvenirs from the station shops. So, the sales increase could also be seen in the station's shops and cafes. That is to say, this new promoting method not only solved the financial problem, but also brought more profits to the rail line, and its related business.

\subsection{Finding new uses}

Finding new uses for products can change their function, and these products may play a more important role in another field. However, finding new uses can be hard for a company as they can hardly abandon their initial design, and although it does not happen often, sometimes small adjustments can result in big changes and incredible profits for the company. Take Rubik's Cube as an example. Rubik invented his famous cube which later became the most well-known toy around the world, despite the fact it was initially created as a teaching tool for architecture courses, totally unrelated to toys. However, rather than keeping the cube as an architectural teaching tool, the creator made it into a toy by adding different colours to each side of the cube. Since the cube's launch and global upsurge, it has created millions in sales (Rubik's Brand Ltd., 2018). People from different professions can now enjoy the cube as an intelligence toy and it is especially embraced by teenagers who are interested in puzzle games. Another similar example is the famous British tissue brand Skenney. The thin and soft product was once only used to remove make-up. It was not until 1930 that the idea of using it to blow people's noses came forth when a researcher used it as a substitute for a handkerchief. In that case, advertisements introducing the new use came out immediately and sales doubled in the starting year (KCWW, 2017). After the main function of the tissue changed, the product could then be used by everyone no matter the age or gender. With these examples it is not hard to point out that thinking of new uses can be something that happens occasionally but a much easier idea such as that used by Skenney in its 
adjustment resulted in making the product more useful to more people. If companies bring their products closer to people's daily lives, that means they can suggest a new lifestyle to people and influence their lives. In this case, products will be more accepted by people which consequently increases the sales of the product.

\subsection{Extending product range}

Companies extend their product range to meet more customers' needs. Normally, companies make some little change to the product. They want to provide more choices to the customers. Starbucks provide over 30 kinds of pure and mixed coffee products to its customers. Blends coffee beans are collected from different countries and different areas while mixed have variety of beans in the product. Other than coffee, the company developed some derivative products. For example, the Frappuccino is a kind of icy product which is suitable for hot summer days. It is a product that add ice and cream to make the coffee more like a dessert. They also provide tea in some areas of the world and also non-coffee products for people who are not fond of the coffee flavor (Starbucks Corporation, 2018). Starbucks's diverse products have satisfied many customers and helped it remain in its leading position for many years. Conversely, Coca-Cola BlāK, a derivative product brought out by Coca-Cola in 2006 existed in the market for only one year. This product was mostly designed for people who prefer a bitter taste rather than a sweet taste. The company added coffee flavor to its fizzy drink, an unusual mixture that was not accepted by most people. Although it took the company about two years to work out the recipe, the coffee-flavoured drink was discontinued and quickly left the market over the following years (Obias, 2016). So, the risk of not successfully extending the life of a product still exists after a company pays a lot to adjust it. Sometimes they need to hold more extensive marketing research to better known their customers' needs.

\subsection{Providing a new appearance}

Providing a new appearance can be used to adjust the existing product for the existing market. After re-designing the logo, changing the packaging or renaming the product, companies want to change their products' impression and give their products new life. In reality, this is not suitable for every company. In 2016, Coca-Cola was reported (Roderick, 2016) struggling with a sales decline. In the report sales of the products languishing in the UK and the company's global revenues had decreased 5 percent compared with a year before. To deal with this situation, Coca-Cola started its "One Brand Campaign" in 2017. The company put its four famous products together under a single brand and then re-packaged the products in similar designs with a red circle as the background symbol. In this way, the company hoped to increase the brand identity of its product. Other than changing the image, the company designed slogans for each product and added them to the package. They mainly suggested how suitable the products were for a healthy lifestyle person to enjoy. Though these welldesigned slogans Coca-Cola wanted to emphasize its Sugar free and low-calorie products, this change leads no improvement for the company (Roderick, 2016). There are two reasons for this failure; governments' warnings concerning the risks of being overweight and people's own awareness of their health. Even though the calories were marked on the package, customers' demand did not increase. As long as relaunching a product costs a huge amount of money, most companies will only use this way on their decling products which still retain great potential value and meet consumers' needs.

\section{Conclusion}

In conclusion, there are six points I have mentioned in all, and they can be divided and put under two main strategies. Holding marketing campaigns, targeting new markets and finding new unique selling points are for product promotion. Finding new uses, providing a new appearance and extending product range belong to product adjustment. They all have their pros and cons. More people will observe the product through a campaign and at the same time it could fail if the campaign is produced in a controversial way. Extending a products life span requires talent from many fields to develop different areas, especially when globalizing. It is hard for companies to find new unique selling points and new functions for products as the ability to innovate is particularly required. Designing a new appearance is always cost-effective, so companies should estimate their products' remaining value before they decide to relaunch them. Extending the range needs an in-depth marketing research to know what kind of adjustment customers want on the company's existing products. By adopting these two strategies, companies can make plans to deal with a product's circumstances, especially a drop in sales. However, it is essential that these strategies are used properly. If not, counterproductive results can occur.

\section{References}

[1] China Vanke Co.,Ltd (n.d.). Group Overview. [online] vanke. Available at: https://www.vanke.com/en/about.aspx [Accessed 25 Nov. 2018]. 
[2] Fill, C. (2002). Marketing communications: contexts, strategies and applications. 3rd ed. Harlow: Financial Times Prentice Hall.

[3] Forbes Media LLC. (2018). [online] Forbes.com. Available at: https://www.forbes.com/powerful-brands/list/\#tab:rank [Accessed 25 Nov. 2018].

[4] Hobbs, T. (2017). Pepsi's tone deaf Kendall Jenner ad deserves to be criticised. [online] Marketing Week. Available at: https://www.marketingweek.com/2017/04/05/why-pepsi-kendall-jenner-got-it-wrong/ [Accessed 25 Nov. 2018].

[5] KCWW (2017). The Kleenex ${ }^{\circledR}$ Brand Story. [online] Kleenex.com.my. Available at: https://www.kleenex.com.my/msmy/brand-story [Accessed 24 Nov. 2018].

[6] Marcouse, I., Watson, N. and Hammond, A. (2015). AQA Business for A Level (Marcousé). London: Hodder Education Group, p.134.

[7] Marketing Week Reporters (2017). 2017 year in review: Campaigns of the year - Marketing Week. [online] Marketing Week. Available at: https://www.marketingweek.com/2017/12/04/campaigns-of-2017/ [Accessed 24 Nov. 2018].

[8] McCurry, J. (2015). Tama the cat: 3,000 attend elaborate funeral for Japan's feline stationmaster. [online] the Guardian. Available at: https://www.theguardian.com/world/2015/jun/29/tama-the-cat-3000-attend-elaborate-funeral-for-japans-feline-stationmaster [Accessed 24 Nov. 2018].

[9] Obias, R. (2016). 12 Discontinued Products From Coca-Cola and Pepsi. [online] Mentalfloss.com. Available at: http:// mentalfloss.com/article/66433/12-discontinued-products-coca-cola-and-pepsi [Accessed 26 Nov. 2018].

[10] Roderick, L. (2016). Coca-Cola sees 'green shoots' as One Brand strategy makes 'promising' start - Marketing Week. [online] Marketing Week. Available at: https://www.marketingweek.com/2016/09/07/coca-cola-sees-green-shoots-asone-brand-strategy-yields-promising-results/ [Accessed 25 Nov. 2018].

[11] Rubik's Brand Ltd. (2018). About us. [online] Uk.rubiks.com. Available at: https://uk.rubiks.com/about [Accessed 25 Nov. 2018].

[12] Starbucks Corporation (2018). Starbucks Company Profile. [online] Starbucks Coffee Company. Available at: https:// www.starbucks.com/about-us/company-information/starbucks-company-profile [Accessed 27 Nov. 2018].

[13] van Daalen, T. (2012). Product adjustment :: IRC. [online] Ircwash.org. Available at: https://www.ircwash.org/news/ product-adjustment [Accessed 26 Nov. 2018].

[14] Vanke Real Estate (Hong Kong) Company Limited (2017). Annual report for the year ended 31 December 2016. [online] Available at: https://www.vanke.com/en/upload/file/2017-06-08/af813e94-16bb-4068-8a40-eadaf8f0813b.pdf [Accessed 25 Nov. 2018]. 